University of Nebraska - Lincoln

DigitalCommons@University of Nebraska - Lincoln

7-23-2008

\title{
Effects of global irrigation on the near-surface climate
}

\author{
William J. Sacks \\ University of Wisconsin - Madison \\ Benjamin I. Cook \\ Lamont-Doherty Earth Observatory \\ Nikolaus Buenning \\ University of Colorado at Boulder \\ Samuel Levis \\ National Center for Atmospheric Research \\ Joseph H. Helkowski \\ Earth Tech, Miami, Florida
}

Follow this and additional works at: https://digitalcommons.unl.edu/nasapub

Part of the Physical Sciences and Mathematics Commons

Sacks, William J.; Cook, Benjamin I.; Buenning, Nikolaus; Levis, Samuel; and Helkowski, Joseph H., "Effects of global irrigation on the near-surface climate" (2008). NASA Publications. 5.

https://digitalcommons.unl.edu/nasapub/5

This Article is brought to you for free and open access by the National Aeronautics and Space Administration at DigitalCommons@University of Nebraska - Lincoln. It has been accepted for inclusion in NASA Publications by an authorized administrator of DigitalCommons@University of Nebraska - Lincoln. 


\title{
Effects of global irrigation on the near-surface climate
}

\author{
William J. Sacks · Benjamin I. Cook • \\ Nikolaus Buenning · Samuel Levis · \\ Joseph H. Helkowski
}

Received: 5 February 2008/ Accepted: 2 July 2008/Published online: 23 July 2008

(c) Springer-Verlag 2008 This article is a U.S. government work, and is not subject to copyright in the United States.

\begin{abstract}
Irrigation delivers about $2,600 \mathrm{~km}^{3}$ of water to the land surface each year, or about $2 \%$ of annual precipitation over land. We investigated how this redistribution of water affects the global climate, focusing on its effects on near-surface temperatures. Using the Community Atmosphere Model (CAM) coupled to the Community Land Model (CLM), we compared global simulations with and without irrigation. To approximate actual irrigation amounts and locations as closely as possible, we used national-level census data of agricultural water withdrawals, disaggregated with maps of
\end{abstract}

\section{W. J. Sacks (ه)}

Center for Sustainability and the Global Environment,

University of Wisconsin-Madison, 1710 University Avenue,

Madison, WI 53726, USA

e-mail: wsacks@wisc.edu

\section{B. I. Cook}

Ocean and Climate Physics, Lamont-Doherty Earth Observatory,

61 Route 9W, P.O. Box 1000, Palisades, NY 10964-8000, USA

\section{B. I. Cook}

NASA Goddard Institute for Space Studies, 2880 Broadway,

New York, NY 10025, USA

\section{N. Buenning}

Department of Atmospheric and Oceanic Sciences and Cooperative Institute for Research in Environmental Sciences, University of Colorado-Boulder, 216 UCB,

Boulder, CO 80309-0216, USA

\section{S. Levis}

Climate and Global Dynamics Division, National Center for Atmospheric Research, P.O. Box 3000,

Boulder, CO 80307, USA

\section{J. H. Helkowski}

Earth Tech, 3750 N.W. 87th Ave Suite 300,

Miami, FL 33178, USA croplands, areas equipped for irrigation, and climatic water deficits. We further investigated the sensitivity of our results to the timing and spatial extent of irrigation. We found that irrigation alters climate significantly in some regions, but has a negligible effect on global-average near-surface temperatures. Irrigation cooled the northern mid-latitudes; the central and southeast United States, portions of southeast China and portions of southern and southeast Asia cooled by $\sim 0.5 \mathrm{~K}$ averaged over the year. Much of northern Canada, on the other hand, warmed by $\sim 1 \mathrm{~K}$. The cooling effect of irrigation seemed to be dominated by indirect effects like an increase in cloud cover, rather than by direct evaporative cooling. The regional effects of irrigation were as large as those seen in previous studies of land cover change, showing that changes in land management can be as important as changes in land cover in terms of their climatic effects. Our results were sensitive to the area of irrigation, but were insensitive to the details of irrigation timing and delivery.

Keywords Irrigation - GCM · Agriculture . Land management

\section{Introduction}

Humans are modifying the earth's climate not only by changing the composition of the atmosphere, but also by changing the land surface. Both the conversion of forests to croplands and the conversion of vegetated landscapes to cities can have large effects on the regional climate. These effects manifest themselves through changes in the partitioning of net radiation into sensible $(\mathrm{H})$ and latent heat (LE) fluxes, changes in albedo, and changes in the 
surface roughness length (Foley et al. 2003). On the global average, the biophysical effects of historical deforestation on temperature seem to have been no larger than $0.1-0.2 \mathrm{~K}$, suggesting that they are relatively unimportant. But this ignores important regional climate changes: the conversion of forests to croplands may have cooled some northern midlatitude regions by $\sim 1 \mathrm{~K}$ or more, according to several global modeling studies (Brovkin et al. 1999; Govindasamy et al. 2001; Zhao et al. 2001; Bounoua et al. 2002; Matthews et al. 2004; Betts et al. 2007).

In addition to these changes in land cover, humans can also affect the climate through changes in land management. Two farms growing the same crop may have different effects on the local climate because of differences in management practices. For example, no-till agriculture, in which crop residues are left on the field, increases albedo and suppresses soil evaporation (Lobell et al. 2006, hereafter L06; Kucharik and Twine 2007). Double-cropping also affects the climate, by increasing the length of time in which the surface is covered by photosynthesizing and transpiring vegetation. Both of these practices affect surface temperatures directly, as well as modifying the carbon and water cycles (Schlesinger 1999).

Irrigation is perhaps the management practice that can have the largest effect on climate. The addition of water to the land surface tends to increase LE and decrease $\mathrm{H}$. This increase in evapotranspiration leads to a cooling of the land surface. Under certain conditions, the resulting increase in atmospheric water vapor may also enhance cloud cover and downstream precipitation. Irrigation can also modify regional circulation patterns, by creating temperature contrasts between cool, moist irrigated areas and nearby hotter, drier non-irrigated areas (e.g., Kueppers et al. 2007).

As of the year 2000, global agriculture used about $2600 \mathrm{~km}^{3}$ of water each year (Shiklomanov 2000), equivalent to $17 \mathrm{~mm}$ of water spread evenly over the land surface. This is a 75\% increase from 1960 levels, and a $400 \%$ increase from 1900 levels of irrigation (Shiklomanov 2000). Although only $18 \%$ of the world's croplands-or about $2 \%$ of the total land surface-are irrigated, these irrigated croplands produce $40 \%$ of the world's food (Siebert et al. 2005). On average, these irrigated areas experience an addition of $800 \mathrm{~mm}$ of water each year, although this value varies considerably from region to region and from crop to crop.

The irrigation cooling effect is large enough to be seen in long-term temperature records near irrigated areas. For example, Bonfils and Lobell (2007) compared temperature trends in irrigated areas in California's Central Valley with those in nearby non-irrigated areas. They found that irrigation there has decreased summertime maximum temperatures in heavily-irrigated areas by $\sim 2-3 \mathrm{~K}$. Similarly, Mahmood et al. (2006) found an irrigation-induced cooling of $\sim 1 \mathrm{~K}$ in maximum growing season temperatures in irrigated areas in Nebraska.

Modeling studies have also shown significant climatic effects of irrigation, although they have disagreed about the magnitude and spatial pattern of these effects. Most of these modeling studies have been regional rather than global (e.g., Chase et al. 1999; Adegoke et al. 2003; Haddeland et al. 2006; Kueppers et al. 2007). For example, Kueppers et al. (2007) investigated the irrigation cooling effect over California. They found that the conversion of natural vegetation to irrigated crops has cooled irrigated areas by $\sim 3.7 \mathrm{~K}$ in August and $\sim 1.6 \mathrm{~K}$ yearround. Averaged over all of California, they found that irrigation (along with other land cover changes) has decreased August temperatures by $\sim 0.4 \mathrm{~K}$. Haddeland et al. (2006) found qualitatively similar, but smaller temperature decreases over the Colorado and Mekong river basins due to irrigation. Differences in the magnitude of the irrigation cooling effect between these studies can be partly explained by differences in how irrigation was modeled. Haddelend et al. (2006) only irrigated in their model when transpiration became limited by soil moisture, and only irrigated over a fraction of each grid cell. The amount of water they added through irrigation matched observations. Kueppers et al. (2007), in contrast, performed their irrigation by holding root zone soil moisture fixed at field capacity year-round in irrigated grid cells. They did not report how much water they added through irrigation, an omission common to many irrigation modeling studies.

Two recent global modeling studies also showed that irrigation cools the near-surface climate, but disagreed about the magnitude of this cooling (Boucher et al. 2004, hereafter B04; L06). As in the aforementioned regional modeling studies, differences between the irrigation algorithms of B04 and L06 can explain much of the discrepancy between these studies. L06 modeled irrigation by holding soil moisture in all croplands fixed at saturation during the growing season. They acknowledged that this is an "extreme" scenario, but did not estimate how extreme it is. They used the community atmosphere model (CAM) coupled to the community land model (CLM), a sophisticated land surface scheme (Oleson et al. 2004). Irrigation, as they modeled it, caused a global land surface cooling of $1.3 \mathrm{~K}$, and regional cooling of up to $8 \mathrm{~K}$. B04, in contrast, constrained their irrigation to match quantities and locations given by observations. They did this by directly prescribing the evapotranspiration flux from irrigation (but they allowed the natural latent heat flux to adjust dynamically, so the net additional latent heat flux in their irrigation experiment was less than the 
prescribed irrigation flux). Using the Laboratoire de Météorologie Dynamique General Circulation Model (LMDZ), which has a simple bucket model land surface scheme, they found that irrigation causes a global cooling of $0.05 \mathrm{~K}$ and regional cooling of up to $0.8 \mathrm{~K}$. These climatic changes are still appreciable, but they are much smaller than those shown by L06.

In this study, as in B04 and L06, we estimate the effects of global irrigation on today's climate. However, unlike the previous studies, we strive to apply a realistic amount of irrigation water and explicitly calculate the effects on the surface water and energy balance. To do this, we use a global irrigation map based on census data from the Food and Agricultural Organization of the United Nations (FAO) (Helkowski 2004; Foley et al. 2005). In contrast to B04, we add the irrigation water directly to the land surface and allow the land model to determine the fraction evaporated or transpired. Thus, we combine the most realistic aspects of L06 and B04-we use a sophisticated land surface model that calculates the partitioning between evapotranspiration and runoff, as in L06, and an observation-based data set of the locations and amounts of irrigation, as in B04. In addition to examining the effects of irrigation in a coupled landatmosphere model, we also examine the sensitivity of these effects to the method of irrigation-specifically related to the timing of irrigation water delivery, an aspect of land-atmosphere interactions that has not been considered before. Finally, we put our results in context by comparing them with the results of other irrigation and land cover change studies.

\section{Methods}

\subsection{Irrigation data set}

We created a global gridded data set of average annual irrigation water withdrawals by combining national-level census data of agricultural water use with maps of croplands, areas equipped for irrigation, and climatic water deficit (Helkowski 2004; also reported in Foley et al. 2005). Census data were primarily taken from the FAO's AQUASTAT database (FAO 2004), but were augmented by additional sources for countries absent from that database (Gleick 1998; Kuo 2001). We supplemented these national data with state-level data for the United States (USGS 2004) and province-level data for China (China State Statistical Bureau 2004). Data for the year 2000 were used where possible. These data sets specify water withdrawals, which are often greater than the amount of water that gets applied to crops, due to losses in transport and application. This overestimates the amount of water seen by the crops. Total water withdrawals, however, are the important quantity from an energy balance perspective-water evaporated during transport cools the surface just like water applied to fields. Residential "irrigation"- the watering of lawns and gardens-is not included in these data sets.

We disaggregated the census data to a $0.5^{\circ} \times 0.5^{\circ}$ grid using three weighting maps (Fig. 1):

1. Fractional cropland area (Leff et al. 2004): This factor accounted for both the total cultivated fraction of each grid cell and the crop type. Rice, sugar cane and cotton
Fig. 1 Weighting maps used to disaggregate the irrigation data: a fractional cropland area (rice, sugar cane and cotton are given double weighting), $\mathbf{b}$ fractional area equipped for irrigation, $\mathbf{c}$ ratio of actual evapotranspiration to potential evapotranspiration, averaged over the growing season. The total relative weight for each grid cell is $(\mathbf{a}) \times(\mathbf{b}) \times(1-(\mathbf{c}))$
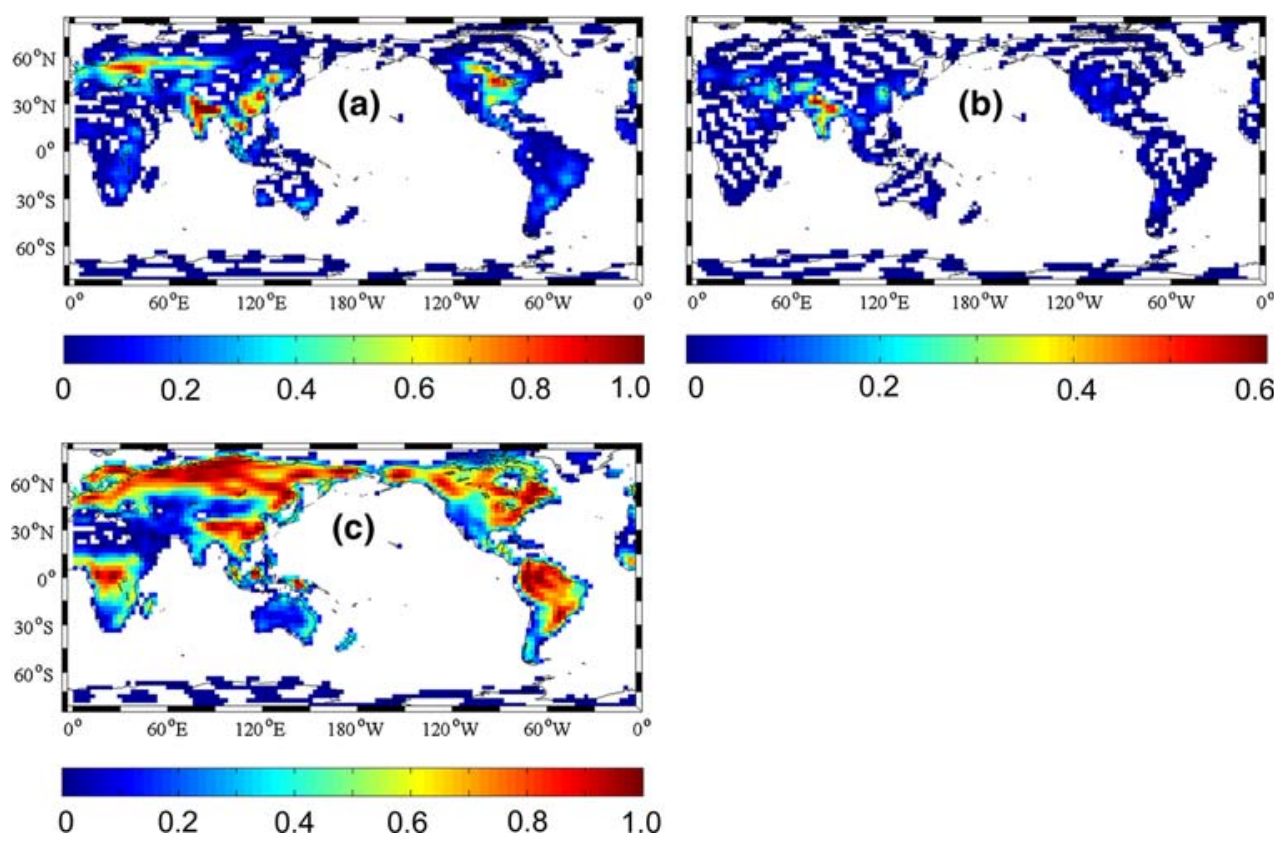
were given double the weighting of all other crops, since these three crops require more water (the total "fractional area" could, therefore, be greater than one).

2. Fractional area equipped for irrigation (Siebert et al. 2001).

3. Annual climatic water deficit: this weight was defined as one minus the ratio of actual evapotranspiration to potential evapotranspiration, which we computed using a simple water balance model (Helkowski 2004). We used climatological averages over the growing season (defined as months with a mean temperature greater than $5^{\circ} \mathrm{C}$ ).

These three weights were multiplied together to determine a total relative weight for each grid cell. We distributed the census-derived values among the grid cells in each political unit according to these weights. This allowed the spatial distribution of water withdrawals to be non-uniform within a political unit, but conserved the total amounts given in the census data.

Finally, we regridded this $0.5^{\circ} \times 0.5^{\circ}$ map to T42 resolution (approximately $2.8^{\circ} \times 2.8^{\circ}$ ), the resolution we used for our climate model simulations.

\subsection{Land and atmosphere models}

We used version 3.5 of the Community Land Model (CLM3.5, hereafter simply referred to as CLM) (Oleson et al. 2004; Dickinson et al. 2006; Oleson et al. 2008). The processes modeled by CLM include: solar and longwave radiation interactions with the plant canopy and soil; momentum, sensible and latent heat fluxes; heat transfer in soil and snow; canopy, snow and soil hydrology; and stomatal physiology and photosynthesis (Oleson et al. 2004; 2008). The water balance of each grid cell is given by:

$$
\begin{aligned}
& \Delta W_{\text {can }}+\Delta W_{\text {sno }}+\sum_{i=1}^{10}\left(\Delta w_{\text {liq }, i}+\Delta w_{\text {ice }, i}\right) \\
& \quad=\left(q_{\text {rain }}+q_{\text {sno }}-E_{t}-E_{i}-E_{g}-q_{\text {over }}-q_{\text {drai }}-q_{\text {rgwl }}\right) \Delta t
\end{aligned}
$$

where $W_{\text {can }}$ is canopy water, $W_{\text {sno }}$ is snow water, $w_{\text {liq, } i}$ is liquid water in soil layer $i$, and $w_{\text {ice, } i}$ is soil ice in layer $i$ (all in $\mathrm{mm}$ ); $q_{\text {rain }}$ is liquid precipitation, $q_{\text {sno }}$ is solid precipitation, $E_{t}$ is vegetation transpiration, $E_{i}$ is evaporation of water intercepted by vegetation, $E_{g}$ is ground evaporation, $q_{\text {over }}$ is surface runoff, $q_{\text {drai }}$ is sub-surface drainage, $q_{\mathrm{rgwl}}$ is runoff from glaciers, wetlands and lakes (all in $\mathrm{mm} \mathrm{s}^{-1}$ ), and $\Delta \mathrm{t}$ is the time step (s). There are ten soil layers, with a total depth of $3.4 \mathrm{~m}$ (Oleson et al. 2004).

Version 3.5 of CLM contains a number of improvements over CLM3. These improvements, summarized by Oleson et al. (2008), mainly serve to make the modeled hydrology better match observations. For example, a soil resistance term was added for the soil latent heat flux, and a scaling factor was added for canopy interception, improving the partitioning of evapotranspiration.

Each grid cell in CLM can contain multiple plant functional types (PFTs). We specified the PFT coverage in each grid cell using the data set of Lawrence and Chase (2007). Natural vegetation cover in this data set is based on the MODIS Vegetation Continuous Fields data set (Hansen et al. 2003), and crop cover is based on the historical crop maps of Ramankutty and Foley (1999). We also prescribed the time course of leaf area index (LAI) for each PFT in each grid cell using Lawrence and Chase's (2007) data. These data were derived from the MODIS monthly LAI data set of Myneni et al. (2002). The monthly LAI values, which represent climatological averages for 2001-2003, were linearly interpolated to give daily LAI.

In its standard configuration, CLM allows up to four PFTs to occupy a single grid cell. One of these PFTs may be a generic "crop"; the rest are either one of 14 natural vegetation types or bare ground. These four PFTs share a single soil column, so all have the same level of water availability. With the introduction of irrigation, this shared soil column leads to the unrealistic result that even natural vegetation is irrigated. For our simulations, we therefore divided the soil in each grid cell into two separate columns: one for crops (if present) and one for four natural PFTs. We made this modification for both the control runs and the irrigated runs.

For our coupled simulations, we interactively coupled CLM to version 3 of the Community Atmosphere Model (CAM) (Collins et al. 2004, 2006; Hurrell et al. 2006). We ran the model using the spectral Eulerian dynamical core at T42 resolution, with 26 levels in the vertical and a 20minute time step. We used climatological sea surface temperatures rather than an ocean model to decrease interannual variability, thus increasing the signal-to-noise ratio of irrigation's effects on climate. The initial conditions for the model were taken from a 150-year spin-up to ensure a near-equilibrium initial state.

\subsection{Irrigation modeling}

We used the irrigation data set, described above, to prescribe the locations and annual amounts of irrigation in the model. However, this data set does not prescribe the timing of irrigation. We assumed that irrigation occurs around the peak of the growing season. Specifically, in each grid cell, we irrigated whenever crop LAI was at least $80 \%$ of the maximum annual LAI in that grid cell. In grid cells where crops were present but were not one of the four dominant PFTs, we instead determined the irrigation period using one of the dominant PFTs, with a preference for grass 
PFTs. Although this use of non-crop LAIs was only necessary for the O-IRRIG SSoil $_{1}$ run (described below), we applied this rule in all simulations for consistency. Because LAIs did not vary interannually, the timing of irrigation was the same in every year.

Then, whenever LAI exceeded the $80 \%$ threshold, we irrigated at the following rate:

$I_{i}=\frac{I_{\mathrm{ann}, i}}{86,400 \cdot I_{\mathrm{ND}, i}} \cdot \frac{1}{A_{\text {crop }, i}}$

where $I_{i}$ is the irrigation rate over the crop soil column in grid cell $i\left(\mathrm{~mm} \mathrm{~s}^{-1}\right), I_{\mathrm{ann}, i}$ is the annual irrigation in grid cell $i$ from the input irrigation data set (mm year ${ }^{-1}$, averaged over the entire grid cell), $I_{\mathrm{ND}, i}$ is the number of days of irrigation per year in grid cell $i$, and $A_{\text {crop, } i}$ is the fractional area of the crop column in grid cell $i$. Thus, for a given grid cell, the irrigation rate did not vary within the irrigation season or between years. Irrigation only occurred over the crop soil column. This means that we did not irrigate at all in grid cells where the CLM land surface data had no crops, even if our irrigation data set called for irrigation there. Such grid cells accounted for $7 \%$ of global irrigation volume.

We applied the irrigation by adding $I_{i}$ to the rain rate. However, the irrigation flux bypassed canopy interception, simulating an irrigation method similar to flood irrigation, the most common type of irrigation (Postel 1999). We spread the irrigation evenly throughout the day, with a little occurring in each time step.

\subsection{Simulations}

We performed two 30-year coupled simulations: one with irrigation (C-IRRIG) and a control run without irrigation (C-NOIRRIG) (Table 1). Although we initialized the model in a spun-up state, this spin-up was done without irrigation and with the default CLM configuration of all PFTs in a grid cell sharing a single soil column. Thus, for both simulations, we discarded the first nine years as additional spin-up, and performed comparisons using the last 21 years.

In addition to these coupled runs, we also performed a series of offline experiments with CLM to test the sensitivity of our results to the timing and spatial extent of irrigation (Table 1). We tested sensitivity to irrigation area through the run O-IRRIG ${ }_{1 \text { Soil. }}$ In this run, the cropland and natural vegetation all shared a single soil column, so if irrigation occurred anywhere in a grid cell, it was spread evenly over all the vegetation. This increased the area of irrigation, but the irrigation volume in each grid cell remained the same as in the coupled runs. There was a slight difference, however, in the total global irrigation volume. Grid cells where our irrigation data set called for irrigation but where CLM's input data had no crops were not irrigated in the simulations with a separate crop soil column, because in those runs we only irrigated over crops. These grid cells were irrigated in $\mathrm{O}^{-I R R I G_{1}}$ Soil $_{\text {, though, }}$ since this simplified the modeling.

Because these grid cells only accounted for $7 \%$ of global irrigation volume, this discrepancy should not have a large effect on our conclusions.

We tested sensitivity to the timing of irrigation through two additional runs: O-IRRIG Midnight $_{\text {and O-IRRIG }}$ Noon. In both runs the irrigation water was applied in a more concentrated pulse, for one hour each day. Again, total irrigation volume remained the same. In the first scenario, irrigation started at midnight local time; in the second, irrigation started at noon.

We ran each offline simulation for ten years, starting from a spun-up state. We discarded the first three years as additional spin-up, and computed differences averaged over the last seven years. We used the forcing data of Qian et al. (2006), for the years 1995-2004. These data merge monthly observations from a number of sources with intramonthly anomalies from the National Centers for Environmental Prediction-National Center for Atmospheric Research (NCEP-NCAR) reanalysis. The resulting data have a 3-hour temporal resolution. The spatial resolution of
Table 1 Model runs performed for this study. Runs are either coupled to CAM3 ("C") or driven by observations ("O"), control ("NOIRRIG") or irrigated ("IRRIG")

Thus, O-IRRIG is the offline analog of C-IRRIG. Subscripts denote a single shared soil column for all vegetation in a grid cell ("1Soil"), or pulse irrigation ("Midnight" or "Noon")

\begin{tabular}{|c|c|c|c|c|c|}
\hline Name & $\begin{array}{l}\text { Coupled } \\
\text { to CAM? }\end{array}$ & Irrigation? & $\begin{array}{l}\text { Separate crop } \\
\text { soil column? }\end{array}$ & $\begin{array}{l}\text { Time of } \\
\text { irrigation }\end{array}$ & $\begin{array}{l}\text { Associated } \\
\text { control run }\end{array}$ \\
\hline C-NOIRRIG & $\checkmark$ & & $\checkmark$ & - & - \\
\hline C-IRRIG & $\checkmark$ & $\checkmark$ & $\checkmark$ & $24 \mathrm{~h}$ & C-NOIRRIG \\
\hline O-NOIRRIG & & & $\checkmark$ & - & - \\
\hline O-NOIRRIG ${ }_{1 \text { Soil }}$ & & & & - & - \\
\hline O-IRRIG & & $\checkmark$ & $\checkmark$ & $24 \mathrm{~h}$ & O-NOIRRIG \\
\hline O-IRRIG ${ }_{1 \text { Soil }}$ & & $\boldsymbol{V}$ & & $24 \mathrm{~h}$ & O-NOIRRIG ${ }_{1 \text { Soil }}$ \\
\hline O-IRRIG ${ }_{\text {Midnight }}$ & & $\checkmark$ & $\checkmark$ & Midnight-1 AM & O-NOIRRIG \\
\hline O-IRRIG ${ }_{\text {Noon }}$ & & $\checkmark$ & $\checkmark$ & Noon-1 PM & O-NOIRRIG \\
\hline
\end{tabular}


the offline runs was the same as that of the coupled runs (roughly $2.8^{\circ} \times 2.8^{\circ}$ ), but the time step was 30 minutes (in contrast to the 20-minute time step of the coupled runs).

\section{Results}

\subsection{Coupled irrigation simulation}

Irrigation distributes about $2,560 \mathrm{~km}^{3}$ of water to the world's agricultural lands each year (Table 2) (this value, derived from our data set, is similar to that given by Shiklomanov (2000)). This irrigation is equivalent to $17 \mathrm{~mm}$ of water spread evenly over the land surface, or $2.1 \%$ of the precipitation over land in the control run of CLM. Of course, this irrigation input is not spread evenly over space or time. Over half of the world's irrigation occurs in India and Southeast Asia (Fig. 2). Most of the remaining irrigation occurs in a band between about $30^{\circ}-$ $45^{\circ} \mathrm{N}$. In our model, the northern mid-latitude irrigation occurred primarily in the boreal summer (June, July and August: JJA), coinciding with the peak of the growing season. Irrigation in India and much of Southeast Asia, in contrast, occurred in autumn (September, October and November: SON) (Fig. 2). Less irrigation occurred in boreal spring (March, April and May: MAM) than in summer and autumn, and even less in boreal winter (December, January and February: DJF).

Globally, irrigation in CLM led to an increase in annual LE of $0.656 \mathrm{~W} \mathrm{~m}^{-2}$ (Table 2; this and all other averages refer only to land areas). This additional evapotranspiration, equivalent to $8.3 \mathrm{~mm}_{\text {year }}{ }^{-1}$ averaged over global land, accounted for $38 \%$ of the extra water added to the surface (most of this extra water was from irrigation, although there was also an increase in precipitation, as discussed below). The rest of the added water was lost through runoff or sub-surface drainage. The largest increases in LE occurred in northern mid-latitude regions in JJA, the months of greatest irrigation (Fig. 3). On average, the increase in LE was ten times greater over irrigated areas than over non-irrigated areas (Table 3). However, there was a large increase in LE in the central United States in JJA (Fig. 3), despite irrigation rates that were lower than in many other regions. This increase in LE can be explained by a regional precipitation increase of nearly $1 \mathrm{~mm}$ day $^{-1}$ in JJA in the irrigation run.

Most of the heavily irrigated regions of India, eastern China and Southeast Asia had small increases in LE relative to the irrigation there (Fig. 3; Table 4). The model predicted that a large fraction of irrigation water in those regions was lost to sub-surface drainage. This was partly due to the already-wet climate in those regions. And in reality, half of the irrigation in this region occurs over rice, which experiences a higher drainage fraction than other crops (Guerra et al. 1998). But the drainage fraction in our model was still unrealistically high, and this result probably partly reflects errors in our modeled seasonality of irrigation. For example, we likely underestimated the fraction of irrigation in India that occurs in the dry season (DJF), since our irrigation seasonality was based on the period of maximum vegetation greenness. Thus, we probably underestimated the effects of irrigation in those heavily irrigated regions.

Near-surface humidity and precipitation both increased over land, probably caused at least in part by the increased evapotranspiration. Specific humidity over land was $0.767 \%$ higher in the irrigation run than in the control run, with larger increases in JJA and SON (Table 2). Precipitation increased by $4.3 \mathrm{~mm}$ year $^{-1}$ over land, $25 \%$ of the irrigation rate. The precipitation increase, like the increases in latent heat flux and specific humidity, peaked in JJA (Table 2). The precipitation increase was much greater over irrigated grid cells than over non-irrigated grid cells (Table 3). But this does not necessarily indicate that the precipitation feedbacks were confined within individual grid cells. Rather, this pattern could simply reflect the fact that most irrigation occurs in the same broad latitudinal band, so precipitation downwind of one irrigated grid cell tends to fall in another irrigated grid cell. This precipitation increase partly explains why global LE increased by nearly twice as much in the coupled run as in the similar offline run (Table 2; compare with O-IRRIG in Table 5).

The global-average near-surface temperature change was near zero (Table 2). Although air temperatures decreased by an average of $0.061 \mathrm{~K}$ over irrigated areas, they increased by $0.079 \mathrm{~K}$ over non-irrigated areas (Table 3). It is possible that the global-average temperature change was dampened somewhat by our use of fixed sea surface temperatures, but a separate set of experiments (not shown) indicated that this dampening effect was probably small. Regionally, there were some significant near-surface temperature changes due to irrigation (Fig. 4; Table 4). Parts of the northern mid-latitudes, including the central and southeast United States, portions of southeast China and portions of southern and southeast Asia, cooled by about $0.5 \mathrm{~K}$ averaged over the year. Much of northern Canada, on the other hand, warmed by about $1 \mathrm{~K}$. Temperature decreases were most extensive in JJA, when large areas of the northern mid-latitudes cooled by $1 \mathrm{~K}$ or more (Figs. 4, 5). These areas of significant cooling coincided with areas of large increases in LE (Fig. 3).

While the increase in LE caused some of the surface cooling seen over irrigated areas, other factors strengthened this cooling. For example, the cooling over the United States and southeast China in JJA was due in part to a decrease in downwelling radiation at the surface (Figs. 4d, 6). This 


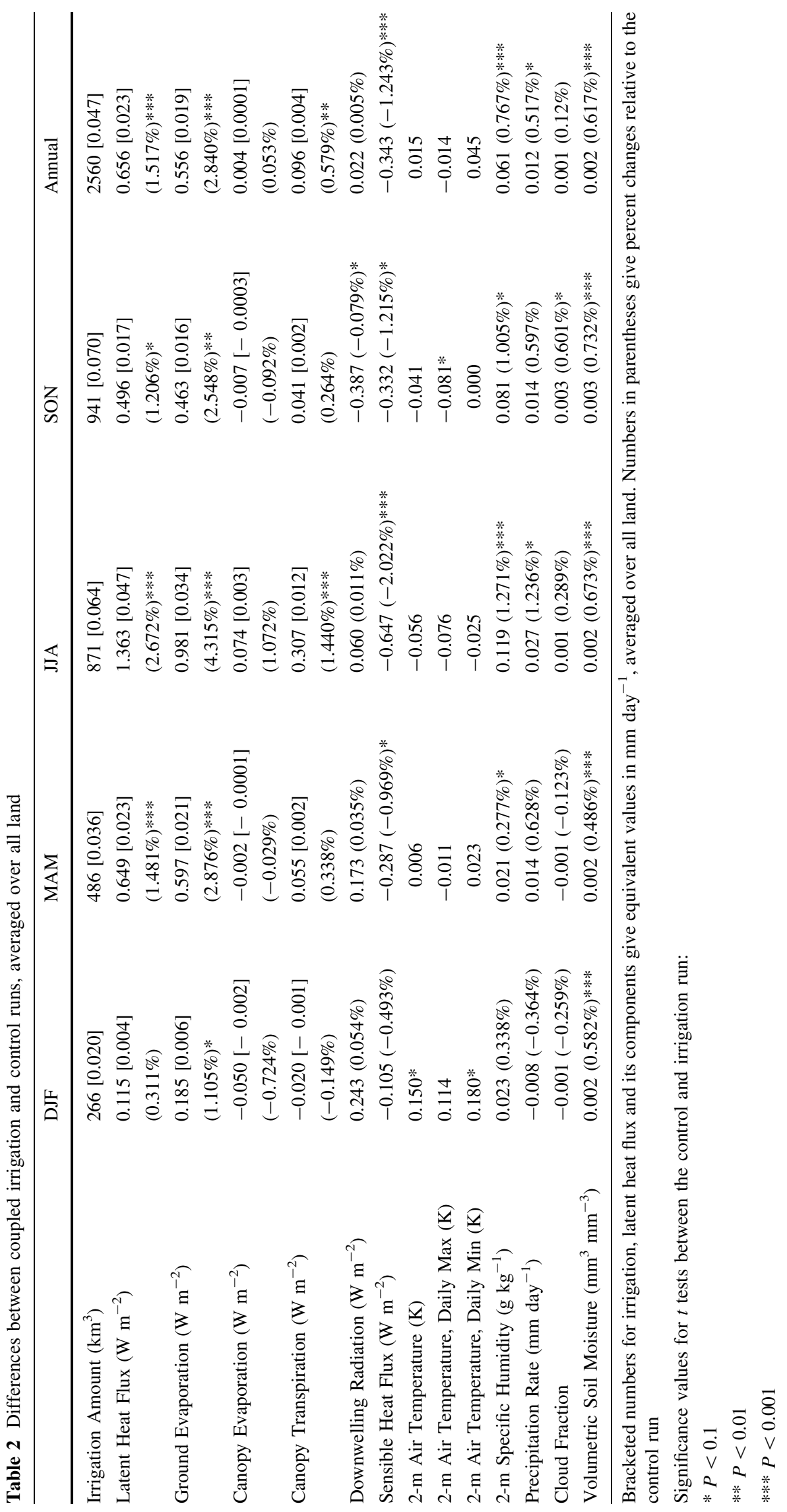


Fig. 2 a Annual irrigation amounts used to force our model $\left(\mathrm{mm}\right.$ year $\left.^{-1}\right)$. This map disaggregates national-level census data (sub-national for the United States and China) using the weighting maps shown in Fig. 1. b-e Seasonal distribution of irrigation in our model, based on when crop LAI exceeded $80 \%$ of its annual maximum for a grid cell: b DJF, c MAM, d JJA, e SON
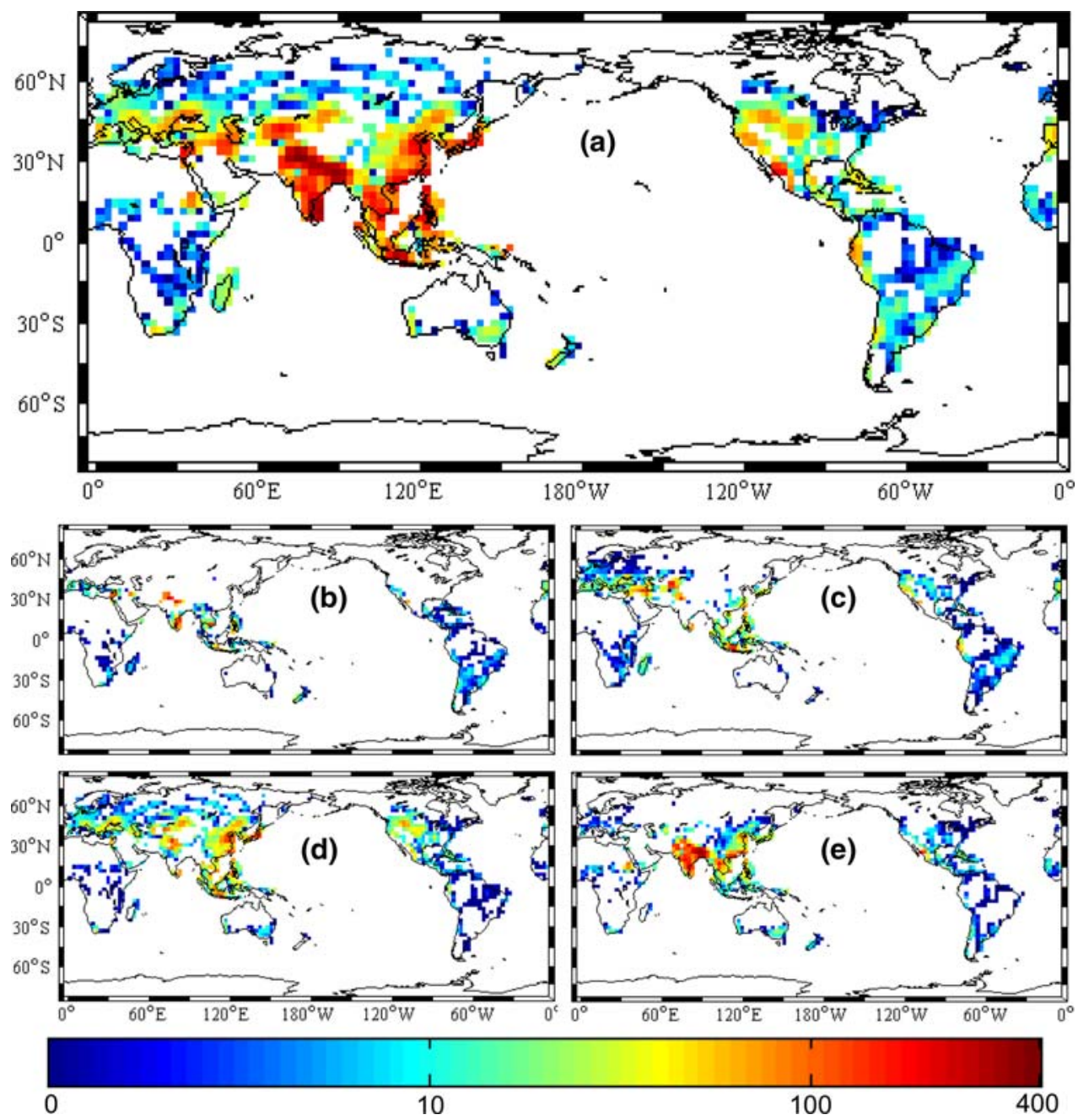

decrease in surface radiation, in turn, was mostly caused by increasing cloud cover, which led to an increased fraction of reflected solar radiation. In fact, even for irrigated areas, changes in surface temperatures were more highly correlated with changes in downwelling radiation (linear regression: $\left.R^{2}=0.49\right)$ than with changes in LE $\left(R^{2}=0.40\right)$. Furthermore, patterns of JJA temperature change over non-irrigated lands were similar to those over heavily irrigated lands. For example, in the northern mid-latitudes, even non-irrigated lands cooled substantially, although this cooling was lower than that over heavily-irrigated areas (Fig. 5). This suggests that, on the scale of a climate model grid cell, much of the cooling effect of irrigation is due to non-local processes such as changes in cloud cover, rather than local evaporative cooling. Indeed, evaporative cooling in one region should be offset by warming from the release of latent heat in other parts of the atmosphere. This offsetting does not necessarily imply zero net temperature change at the surface (the heat may be released higher in the atmosphere, modifying the lapse rate). It does, however, further suggest that indirect effects such as changing cloud cover may be more important for global-average temperature than the direct evaporative cooling from irrigation.

Irrigation exerted a greater cooling effect during the day than at night, and therefore led to a decrease in the diurnal temperature range (Tables 2-4). The average change in daily minimum temperatures over irrigated grid cells was near zero (Table 3). This result is not just an artifact of averaging over space and time: Even over individual grid cells and a single season, irrigation generally had a greater effect on daily maximum temperatures than on daily minimum temperatures. This supports other results suggesting that irrigation mostly affects daytime climate, since its two main cooling effects-evaporative cooling and an increase in cloud-reflected solar radiation-primarily happen during the day (Dai et al. 1999; Duffy et al. 2006).

Offsetting the cooling over irrigated areas, there were areas of significant warming over Canada and northern Alaska in DJF and MAM. It seems that this warming was largely caused by a deepening of the Aleutian Low, a low-pressure system centered off the coast of Alaska in boreal winter. The strengthened low-pressure system 
Fig. 3 a Annually-averaged differences in the surface latent heat flux over land between the irrigated and non-irrigated coupled model runs $\left(\mathrm{W} \mathrm{m}^{-2}\right)$. Positive values indicate a greater latent heat flux with irrigation. All differences shown here are significant at a $95 \%$ confidence level, using 21-year averages. b-e As in a, but for seasonal averages: b DJF, c MAM, d JJA, e SON
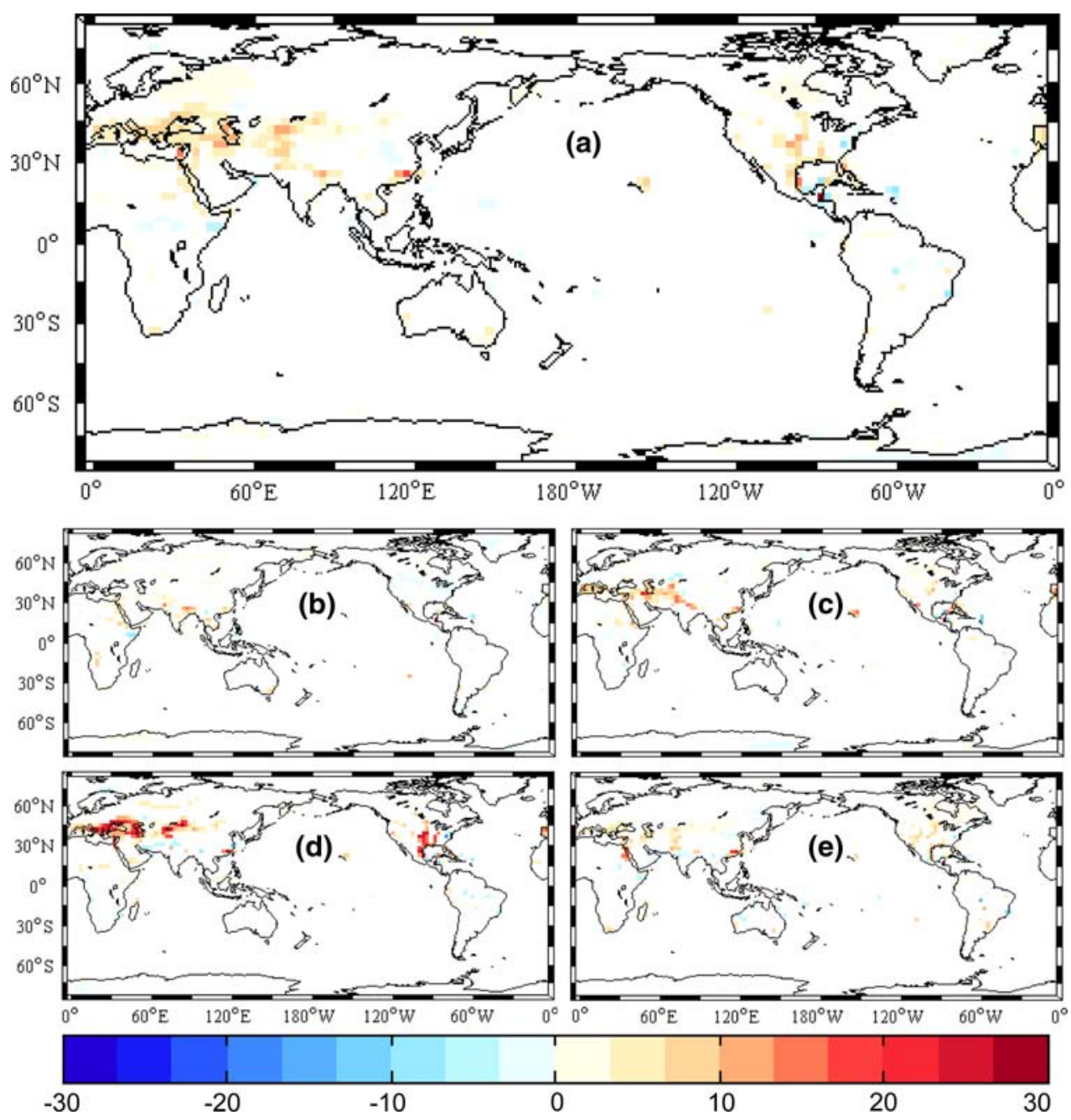

caused the import of more warm, moist air from the Gulf of Alaska onto land. In addition to directly resulting in more heat transport onto land, these shifting dynamics were also associated with a change in the nature of the cloud cover in this region. In DJF, the area of greatest warming coincided with a decrease in low clouds, but an increase in medium and high clouds (low clouds tend to cool the surface, whereas high clouds tend to heat the surface). In MAM, there was a general decrease in cloudcover over the area of greatest warming. Both sets of conditions led to an increase in cloud radiative forcing over the region. The warming in this region was further reinforced by a decrease in snow cover and a consequent decrease in albedo.

As expected, irrigation had a greater effect on temperature in dry regions than in wet regions. For a given level of irrigation, the cooling over grid cells with precipitation lower than the median was much greater than the cooling over grid cells with precipitation higher than the median (Fig. 7).
Albedo only decreased slightly due to irrigation, -0.001 on the annual average, averaged over irrigated grid cells. Wetter soils are darker, but because we only irrigated when LAI was high, the overlying vegetation mostly obscured the changes in soil albedo. In reality, increases in LAI due to irrigation can have a significant effect on the albedo of irrigated areas. However, we prescribed the same time course of LAI in the irrigated and control simulations, so did not allow for this effect.

\subsection{Offline sensitivity analyses}

CLM's default configuration uses a single soil column for all vegetation types in a grid cell. In this study, in contrast, we used a separate soil column for crops in each grid cell. We tested the importance of this splitting of the soil column using two offline runs, O-IRRIG (the offline analog

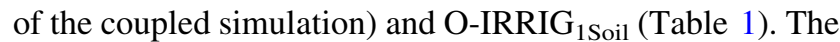
irrigated area was nearly seven times larger in O-IR$\mathrm{RIG}_{1 \text { Soil }}$ than in O-IRRIG. This sevenfold increase in 
Table 3 Annually-averaged differences between coupled irrigation and control runs, split into irrigated versus non-irrigated grid cells, averaged over all land

\begin{tabular}{lll}
\hline & Irrigated Grid Cells & Non-irrigated Grid Cells \\
\hline Irrigation Amount $\left(\mathrm{km}^{3}\right)$ & $2560[0.103]$ & 0 \\
Latent Heat Flux $\left(\mathrm{W} \mathrm{m}^{-2}\right)$ & $1.277[0.044]$ & $0.128[0.004]$ \\
& $(1.928 \%)^{* * *}$ & $(0.339 \%)$ \\
Ground Evaporation $\left(\mathrm{W} \mathrm{m}^{-2}\right)$ & $1.095[0.038]$ & $0.099[0.003]$ \\
& $(4.215 \%)^{* * *}$ & $(0.697 \%)$ \\
Canopy Evaporation $\left(\mathrm{W} \mathrm{m}^{-2}\right)$ & $0.031[0.001]$ & $-0.019[-0.001]$ \\
& $(0.345 \%)$ & $(-0.336 \%)$ \\
Canopy Transpiration $\left(\mathrm{W} \mathrm{m}^{-2}\right)$ & $0.152[0.005]$ & $0.048[0.002]$ \\
& $(0.704 \%)^{* * *}$ & $(0.393 \%)^{*}$ \\
Downwelling Radiation $\left(\mathrm{W} \mathrm{m}^{-2}\right)$ & $-0.441(-0.083 \%)^{*}$ & $0.417(0.091 \%)$ \\
Sensible Heat Flux $\left(\mathrm{W} \mathrm{m}{ }^{-2}\right)$ & $-0.744(-2.251 \%)^{* * *}$ & $-0.002(-0.009 \%)$ \\
2-m Air Temperature $(\mathrm{K})$ & -0.061 & 0.079 \\
2-m Air Temperature, Daily Max $(\mathrm{K})$ & $-0.102 *$ & 0.061 \\
2-m Air Temperature, Daily Min $(\mathrm{K})$ & -0.014 & 0.094 \\
2-m Specific Humidity $\left(\mathrm{g} \mathrm{kg}^{-1}\right)$ & $0.091(0.943 \%)^{* * *}$ & $0.040(0.605 \%)^{*}$ \\
Precipitation Rate (mm day & \\
Cloud Fraction & $0.023(0.860 \%)^{* *}$ & $0.002(0.096 \%)$ \\
Volumetric Soil Moisture $\left(\mathrm{mm}^{3} \mathrm{~mm}^{-3}\right)$ & $0.002(0.485 \%)^{* *}$ & $-0.001(-0.186 \%)$ \\
\hline
\end{tabular}

Bracketed numbers for irrigation, latent heat flux and its components give equivalent values in $\mathrm{mm}$ day $^{-1}$, averaged over either irrigated or nonirrigated grid cells. Numbers in parentheses give percent changes relative to the control run

Significance values for t-tests between the control and irrigation run:

$* P<0.1$

** $P<0.01$

*** $P<0.001$

Table 4 Differences between coupled irrigation and control runs averaged over three regions: the United States $\left(25^{\circ}-50^{\circ} \mathrm{N}, 50^{\circ}-165^{\circ} \mathrm{W}\right)$, India $\left(5^{\circ}-35^{\circ} \mathrm{N}, 70^{\circ}-91^{\circ} \mathrm{E}\right)$, and Eastern China $\left(20^{\circ}-40^{\circ} \mathrm{N}, 108^{\circ}-122^{\circ} \mathrm{E}\right)$; only land points are included

\begin{tabular}{|c|c|c|c|c|c|c|}
\hline & \multicolumn{2}{|l|}{ United States } & \multicolumn{2}{|l|}{ India } & \multicolumn{2}{|l|}{ Eastern China } \\
\hline & JJA & Annual & SON & Annual & JJA & Annual \\
\hline Irrigation amount $\left(\mathrm{km}^{3}\right)$ & $119[0.125]$ & $201[0.053]$ & $492[1.133]$ & $755[0.433]$ & $135[0.679]$ & $246[0.312]$ \\
\hline Latent heat flux $\left(\mathrm{W} \mathrm{m}^{-2}\right)$ & $\begin{array}{l}3.788[0.131] \\
(4.989 \%)^{* * *}\end{array}$ & $\begin{array}{l}1.619[0.056] \\
(3.886 \%)^{* * *}\end{array}$ & $\begin{array}{l}0.968[0.033] \\
(1.482 \%)^{*}\end{array}$ & $\begin{array}{l}1.611[0.056] \\
(2.555 \%)^{* * *}\end{array}$ & $\begin{array}{l}0.108[0.004] \\
(0.100 \%)\end{array}$ & $\begin{array}{l}0.750[0.026] \\
(1.194 \%)^{*}\end{array}$ \\
\hline 2-m Air temperature $(\mathrm{K})$ & $-0.368 *$ & $-0.226^{*}$ & $-0.187 *$ & $-0.202 *$ & $-0.270 *$ & $-0.222 *$ \\
\hline 2-m Air temperature, daily $\max (\mathrm{K})$ & $-0.482^{*}$ & $-0.286^{*}$ & $-0.281 * *$ & $-0.294^{*}$ & $-0.492 *$ & $-0.351 * *$ \\
\hline 2-m Air temperature, daily $\min (\mathrm{K})$ & $-0.211^{*}$ & -0.153 & -0.114 & -0.120 & -0.066 & -0.125 \\
\hline
\end{tabular}

Bracketed numbers for irrigation and latent heat fluxes give equivalent values in $\mathrm{mm} \mathrm{day}^{-1}$, averaged over the region. Numbers in parentheses give percent changes relative to the control run

Significance values for $t$ tests between the control and irrigation run:

$* P<0.1$

$* * P<0.01$

*** $P<0.001$

irrigated area led to a $67 \%$ increase in global-average $\Delta \mathrm{LE}$ and a $59 \%$ increase in the magnitude of $\Delta \mathrm{TG}$ (where $\Delta \mathrm{LE}$ is the difference in the latent heat flux and $\Delta \mathrm{TG}$ is the difference in ground temperature between the irrigation and control run) (Table 5). Thus, splitting the soil column was indeed important for achieving more realistic results. 
Table 5 Globally and annually-averaged changes in select variables in a set of offline sensitivity analyses (see Table 1 for definitions of the runs)

\begin{tabular}{lcccc}
\hline & O-IRRIG & O-IRRIG & O-IRoil $_{\text {IRIG }}$ & O-IRRIdnight $_{\text {Noon }}$ \\
\hline Irrigated area $\left(\mathrm{km}^{2}\right)$ & $1.35 \times 10^{7}$ & $8.88 \times 10^{7}$ & $1.35 \times 10^{7}$ & $1.35 \times 10^{7}$ \\
Latent Heat Flux $\left(\mathrm{W} \mathrm{m}^{-2}\right)$ & 0.3597 & $0.6017^{* *}$ & $0.3562^{* *}$ & $0.3650^{* *}$ \\
Ground Evaporation $\left(\mathrm{W} \mathrm{m}^{-2}\right)$ & 0.3364 & $0.5656^{* *}$ & $0.3322^{* *}$ & $0.3411^{* *}$ \\
Canopy Transpiration $\left(\mathrm{W} \mathrm{m}^{-2}\right)$ & 0.02587 & $0.03841^{*}$ & $0.02654^{* *}$ & $0.02628^{*}$ \\
Ground Temperature $(\mathrm{K})$ & -0.01904 & $-0.03021^{* *}$ & $-0.01883^{* *}$ & $-0.01920^{* *}$ \\
\hline
\end{tabular}

Values are expressed as the difference between the given run and a comparable control run, with the same soil column configuration but no irrigation. Irrigation volume was approximately the same for all runs

Significance values for paired $t$ tests between the standard irrigation run (O-IRRIG) and each of the other runs:

$* P<10^{-3}$

$* * P<10^{-6}$

Fig. 4 As in Fig. 3, but for differences in 2-m air temperatures due to irrigation (K)
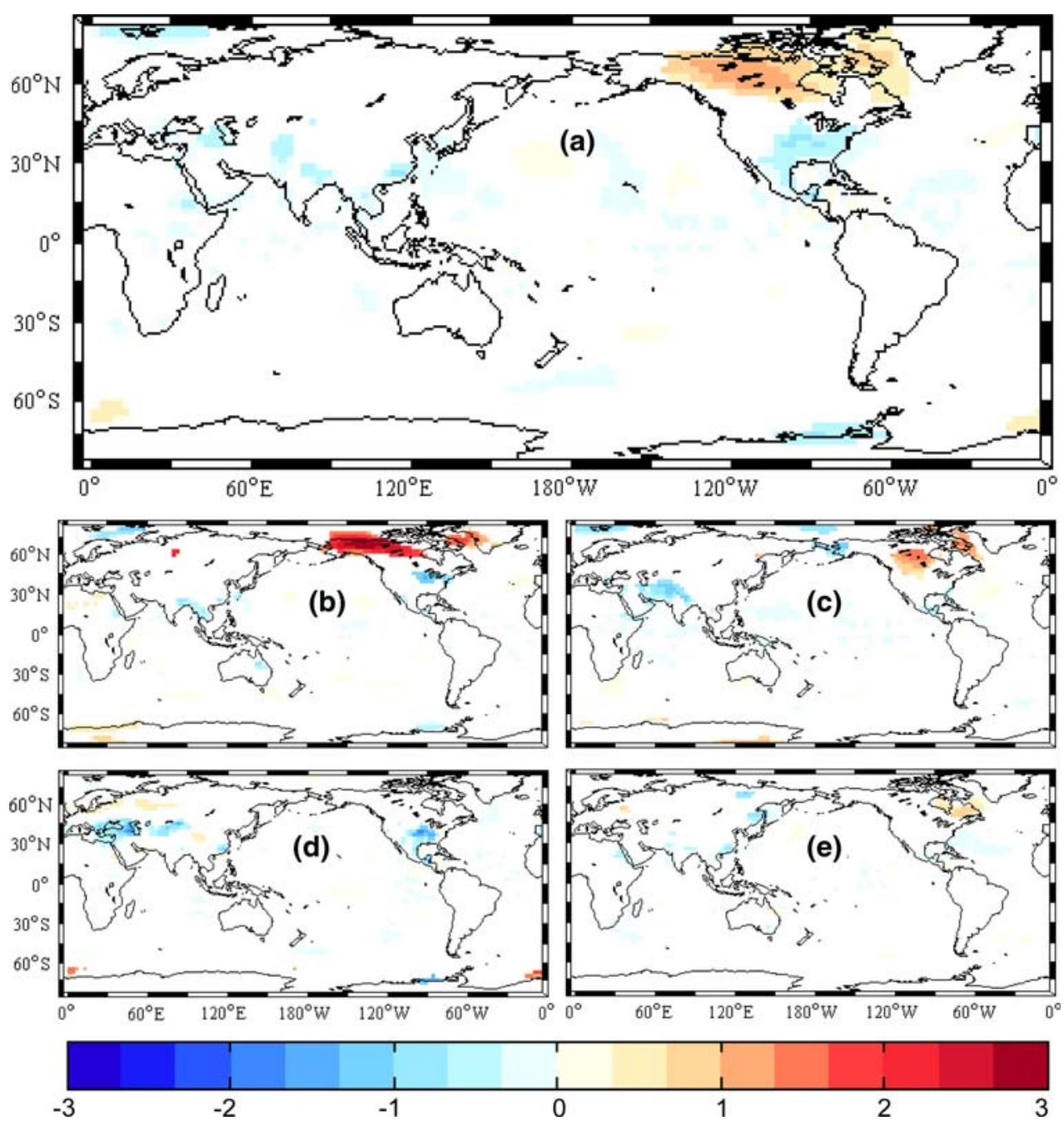

We also tested the model's sensitivity to the timing of irrigation using two additional offline runs, O-IRRIG Midnight and O-IRRIG $_{\text {Noon }}$ (Table 1). Neither pulse irrigation scenario led to very large differences from the standard irrigation run. When averaged globally, the timing of irrigation only had about a $1 \%$ effect on $\Delta \mathrm{LE}$ and $\Delta \mathrm{TG}$ (Table 5). Although small, these differences were statistically significant because of the low internal variability in these offline runs (paired $t$ test on the global, annual averages: $\mathrm{P}<10^{-3}$ for all comparisons shown) (Table 5). 


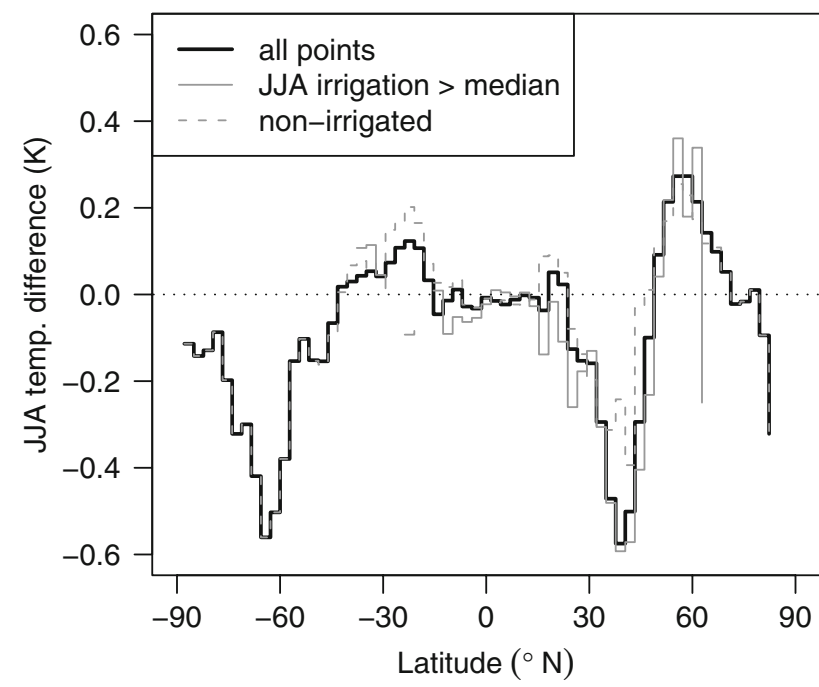

Fig. 5 Zonal averages over land of the difference in JJA 2-m air temperature between the irrigated and non-irrigated coupled model runs $(\mathrm{K})$. The three lines show averages for all land points (dark line), averages for only those points with JJA irrigation greater than median JJA irrigation (where the median includes only irrigated points; light line), and averages for only those land points that are never irrigated (dashed line). The similarity of the three sets of averages, especially in the northern mid-latitudes, suggests that much of the cooling effect of irrigation is due to non-local processes

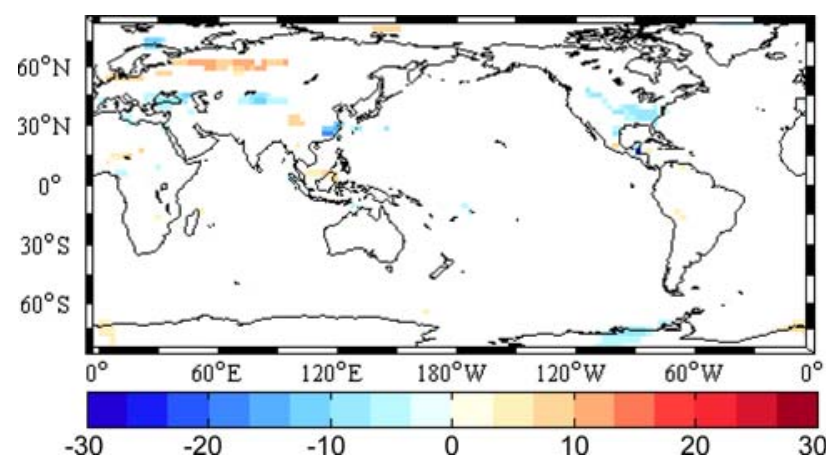

Fig. 6 As in Fig. 3d, but for differences in JJA total downwelling radiation (solar plus longwave) due to irrigation $\left(\mathrm{W} \mathrm{m}^{-2}\right)$. Most of these differences are caused by a change in cloud cover

Compared to the standard irrigation run, noon irrigation caused a slight increase in soil evaporation, while midnight irrigation caused a slight decrease in soil evaporation (Table 5). As we would expect, noon irrigation leads to more immediate evaporation before the water can infiltrate into the soil. The small magnitude of the modeled difference between noon and midnight irrigation is surprising but may be partly due to the lack of atmospheric feedbacks in offline simulations. Also, there may have been a greater difference if we had allowed for canopy interception of some of the irrigation water, as with sprinkler irrigation.

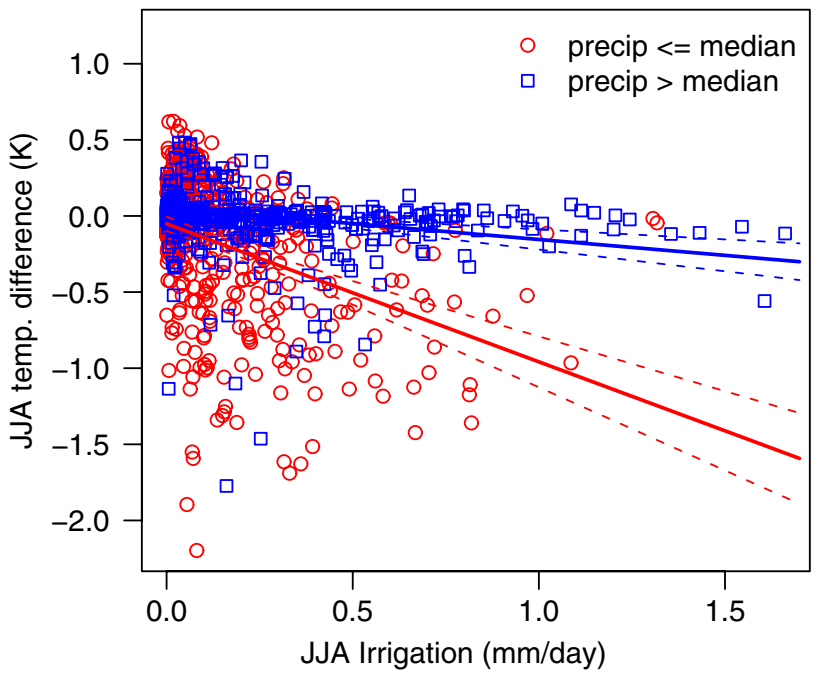

Fig. 7 Differences in JJA 2-m air temperature between the irrigated and non-irrigated coupled model runs, as a function of JJA irrigation amount. Each point represents one irrigated grid cell. The relationship is separated into points with precipitation less than the median (red circles) and points with precipitation greater than the median (blue squares). The median precipitation is $2.43 \mathrm{~mm}^{-1} \mathrm{day}^{-1}$. Irrigation has a much greater effect on temperature in dry areas (best-fit line: $\Delta T=0.052-0.91 \times$ Irrigation; $R^{2}=0.16$ ) than in wet areas (bestfit line: $\Delta T=0.054-0.21 \times$ Irrigation; $\left.R^{2}=0.05\right)$. Linear regressions are shown along with $95 \%$ confidence intervals

\section{Discussion}

\subsection{Comparisons with previous irrigation studies}

We are aware of only one other realistic global-scale study of the effects of irrigation on climate (B04). These authors used a similar irrigation forcing to ours but a different model. As in our study, B04 simulated a cooling over many of the heavily irrigated regions of the world, most notably the United States and Southeast Asia. The magnitude of cooling that they simulated in these regions was similar to that in our study: up to about $0.8 \mathrm{~K}$. However, B04 simulated a warming over some irrigated areas, such as Southern Europe and parts of India, where we simulated a cooling. As in the present study, B04 also simulated a substantial warming over much of the northern high latitudes, although the warming over northern North America in our study was about twice as large as in theirs. B04 found that irrigation caused an average cooling of about $0.05 \mathrm{~K}$ over all land. This global cooling is greater than what our model simulated. But our overall conclusions agree with the results of B04: substantial cooling in some regions-especially the northern sub-tropics and mid-latitudes-is offset by substantial warming in other regionsespecially the northern high latitudes-to yield a near-zero global average temperature change. 
L06 investigated the effects of "extreme scenarios" of irrigation and other agricultural management practices using version 3.0 of CLM coupled to version 3.0 of CAM, a slightly older version of the model used in this study. They found a global cooling of $1.3 \mathrm{~K}$, and regional cooling of up to $8 \mathrm{~K}$ due to irrigation. They performed their irrigation simply by holding soil moisture constant at saturation over croplands during the growing season. We performed a sensitivity test using an irrigation method similar to theirs and came up with similar global temperature changes. Doing so, however, involved adding nearly 100 times more water to the land surface than is actually added by irrigation. Despite the much larger cooling in L06 than in the present study, though, many of our results agreed qualitatively with those of L06. For example, L06 also simulated greater cooling during the day than at night and a substantial cloud feedback that reinforced the irrigation cooling effect.

Thus, the modeled effects of irrigation on climate depend strongly on the amount of irrigation water applied. It is important that future irrigation modeling studies report irrigation volume alongside the effects of irrigation.

A number of regional studies-both modeling and observational-have found effects of irrigation similar to those reported here. Scale differences between these studies and our global study make direct comparison hard, but it is worth examining whether our results are at least in general agreement with these regional studies. Haddeland et al. (2006) simulated an annual irrigation-induced temperature decrease of $0.04 \mathrm{~K}$ and a LE increase of 1.2$1.3 \mathrm{~W} \mathrm{~m}^{-2}$, averaged over the Colorado and Mekong river basins. These effects are similar to the average effects we simulated over all irrigated grid cells (Table 3). Adegoke et al. (2003) simulated an irrigation-induced temperature decrease of $0.6 \mathrm{~K}$ and a LE increase of $23.7 \mathrm{~W} \mathrm{~m}^{-2}$ over Nebraska in July. The areas in our study that exhibited the greatest cooling in JJA had changes in LE roughly comparable to, and changes in near-surface temperatures about twice as large as, these values (Figs. 3, 4). Similarly, Kueppers et al. (2007) simulated an August temperature decrease of $0.38 \mathrm{~K}$ over California, in rough agreement with the JJA temperature changes we simulated in this region. Thus, the magnitude of changes in LE and temperature that we simulated are broadly consistent with those simulated by regional modeling studies.

Some studies have also tried to quantify the climatic effects of irrigation from regional observations. By comparing temperature records from irrigated and non-irrigated areas, Mahmood et al. (2006) and Bonfils and Lobell (2007) deduced the effect of irrigation on temperature in Nebraska and California, respectively. Mahmood et al. (2006) found that irrigation causes a decrease of about $1 \mathrm{~K}$ in mean maximum growing season temperature over irrigated areas of Nebraska. Bonfils and Lobell (2007) found a larger effect: a decrease in daily maximum JJA temperatures of 1.8-3.2 K over irrigated areas of California, and a decrease in daily mean temperatures about twothirds as large. Because these two studies considered the effects of irrigation on small spatial scales, we did not expect to see such large effects in our study. It is encouraging, though, that the greatest temperature decreases that we saw over individual grid cells are approximately as large as the small-scale effects of irrigation seen in these two observational studies. We at least do not seem to be grossly overestimating the effects of irrigation.

\subsection{Comparisons with climate model simulations of global land cover change}

In the past decade, many authors have performed global simulations of the effect of historical anthropogenic land cover change-deforestation and the replacement of natural grasslands with croplands-on climate (e.g., Brovkin et al. 1999; Govindasamy et al. 2001; Zhao et al. 2001; Bounoua et al. 2002; Matthews et al. 2004; Betts et al. 2007). These studies have generally considered only the effects of a change from potential natural vegetation to present-day vegetation cover, and not the effects of other aspects of land management. Here we use the results of these studies to compare the impacts of irrigation with those of land cover change. This comparison indicates how changes in land management compare to changes in land cover in terms of their effects on climate.

We found a very small global-average temperature change due to irrigation (Table 2), even when we averaged over only irrigated grid cells (Table 3). Some land cover change studies showed slightly greater global-average effects. Brovkin et al. (1999), Govindasamy et al. (2001) and Matthews et al. (2004), for example, all simulated a global cooling of a few tenths of a degree. Other land cover change studies showed global effects that were about as small as ours (Zhao et al. 2001; Bounoua et al. 2002; Betts et al. 2007). But in both our study and the above land cover change studies, these small global averages masked larger regional changes. The above land cover change studies tended to find annual cooling effects of up to $0.5-1.0 \mathrm{~K}$ on the scale of a climate model grid cell. Seasonal changes could be somewhat greater, but were almost always less than $2 \mathrm{~K}$. These changes are similar to the largest irrigation-induced temperature changes that we simulated (Fig. 4).

Irrigation and historical land cover change also produce LE variations that are similar in magnitude. Zhao et al. (2001) found an annual increase in global LE of $0.36 \mathrm{~W} \mathrm{~m}^{-2}$; Govindasamy et al. (2001) found an annual increase in global LE over land of $0.8 \mathrm{~W} \mathrm{~m}^{-2}$. These 
values are similar to the increase of $0.656 \mathrm{~W} \mathrm{~m}^{-2}$ that we found over land due to irrigation. Regional changes in LE due to land cover change were generally on the order of 5$10 \mathrm{~W} \mathrm{~m}^{-2}$ (Zhao et al. 2001; Bounoua et al. 2002), also similar in magnitude to those we saw due to irrigation (Table 2, Fig. 3). This and the above results suggest that the inclusion of land management change in earth system models is as important as the inclusion of land cover change.

\subsection{Possible sources of error}

Most of the LE increase in our model was due to an increase in ground evaporation, with only $10-15 \%$ due to an increase in canopy transpiration (Table 2). (The increase in canopy evaporation was much less than the other two component fluxes, because our irrigation scheme bypassed canopy interception.) In the control run, ground evaporation and canopy transpiration accounted for roughly equal proportions of total evapotranspiration. Thus, the extra water added through irrigation was disproportionately evaporated, rather than infiltrating into the soil and being withdrawn later through transpiration. In reality, transpiration should account for much more of the additional LE from irrigation. Although this error may have been due partly to the timing of irrigation in the model, in which irrigation was applied as a small quantity in each time step, this pattern remained the same even in the pulse irrigation

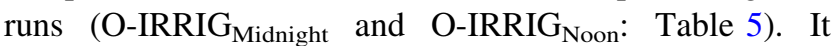
therefore seems that the CLM model did not respond appropriately to this additional water. Even though the partitioning of total LE into evaporation and transpiration probably does not have a large direct impact on the climate, this partitioning is very important for predicting the effect of irrigation on photosynthesis and on the carbon cycle in general. Therefore, this aspect of CLM should be investigated further.

The fraction of added water that was lost to runoff and drainage-62\%-was also unrealistically high. This loss rate is reasonable for rice (Guerra et al. 1998), but too high for other crops. This overestimation of runoff and drainage meant an underestimation of the change in LE. This, in turn, probably caused an underestimation of the effects of irrigation-both the direct evaporative cooling effects and the indirect effects such as changes in cloud cover.

Our overestimation of runoff and drainage was likely caused in part by errors in the modeled seasonality of irrigation in India, eastern China and Southeast Asia. Based on the timing of maximal crop greenness, we simulated that most irrigation in this region happened in SON. Although some irrigation occurred in the dry season (around October-May), much of it occurred either at the end of or shortly after the rainy season. Thus, some of this irrigation water was applied when it was not needed. Doll and Siebert (2002), who incorporated climatic water deficit into their modeling of irrigation seasonality, predicted a greater irrigation demand in this region in DJF and MAM than is suggested by our results. But their approach is not ideal for modeling actual irrigation either. Indeed, they are careful to point out that they are not modeling actual irrigation water use, but rather the amount of irrigation that would be required for optimal crop growth. A lack of adequate water supplies can force farmers to irrigate below the biophysically optimal amount. For example, most wheat in India, which is grown in the dry season, is only irrigated once or twice per season (Joshi et al. 2007) much less than would be predicted by a model of optimal irrigation. So, although our modeled seasonality of irrigation was probably wrong in some locations, it is not clear that another method would have been substantially better.

Although we tried to capture the approximate magnitude of irrigation's effects on climate, we did not attempt to design an irrigation algorithm that was realistic in all respects. First, our aggregation of the irrigation data up to the resolution of a climate model grid cell meant that we irrigated over too large an area. If there was irrigation in any part of a grid cell, then we irrigated the entire crop soil column in that grid cell. Although we conserved irrigation volume, this increase in irrigated area probably led to an overestimation of the effects of irrigation. In the coupled runs, we irrigated $1.35 \times 10^{7} \mathrm{~km}^{2}$ of cropland, or $85 \%$ of all cropland in CLM. In reality, only $18 \%$ of global agricultural areas are irrigated (Siebert et al. 2005). Thus, we irrigated nearly five times too much area. We can estimate the effect of irrigating over too large an area using the results from our O-IRRIG ${ }_{1 \text { Soil }}$ experiment (Table 5). This experiment showed that spreading the irrigation out by another factor of six to seven caused a $67 \%$ increase in the LE change due to irrigation. Thus, we expect that correcting for the errors in the coupled runs due to irrigating nearly all cropland would decrease the modeled effects of irrigation by $25-50 \%$. Future irrigation modeling should account for the fraction of each grid cell that is irrigated (e.g., Siebert et al. 2005).

Second, our irrigation algorithm did not conserve global water. Conceptually, all of the water added through irrigation came from deep aquifers that were outside the model's boundary. In reality, of course, irrigation often diverts water from rivers, and so simply moves water around rather than adding new water to the climate system. The main effect of our not removing irrigation water from rivers is that we overestimated runoff to the oceans. The climate impacts of this overestimation would mainly be felt through changes in ocean circulation. Since we used observed sea surface temperatures, however, these impacts were nonexistent in our study. In reality, some water is also 
evaporated directly from rivers, and our lack of water conservation meant that we failed to account for a decrease in this evaporation flux. CLM does not model river evaporation, but even if it did, this omission would be relatively unimportant. Evaporation from irrigation is much greater than that from rivers because of the greater surface area of the former. Furthermore, in reality, any decreases in the surface area of rivers caused by water withdrawals are probably more than compensated by increases in surface area due to water impoundment for irrigation. We did not account for water impoundment in the model. Overall, the lack of water conservation probably has little effect on our results, although it would be important in a long simulation with a dynamic ocean model.

Third, the timing of irrigation in our model-the application of a small amount of water in every time step throughout the growing season-was not realistic for most irrigation methods. But our offline sensitivity analyses showed that, as far as climatic changes are concerned, the irrigation timing is relatively unimportant (Table 5).

Fourth, our irrigation algorithm treated all agricultural land as the same. For example, we did not distinguish rice from other crops. In addition, we did not distinguish between different forms of irrigation, such as flood irrigation versus sprinkler irrigation. However, in a different set of simulations (not shown) we found that the climatic effects of irrigation were relatively insensitive to whether we applied the water directly to the soil or through the precipitation stream, the latter allowing for canopy interception.

Fifth, we used observed LAI in the model, so did not allow LAI to respond to irrigation, or the lack thereof. In reality, this indirect effect of irrigation on LAI is important for both photosynthesis and climate. The LAI observations used in the model implicitly include the effects of irrigation. Thus, LAI, photosynthesis and transpiration were probably all too high in irrigated grid cells in the control run, leading to an underestimation of the effects of irrigation.

Thus, our irrigation over too large an area and our lack of water conservation probably led to an overestimation of the effects of irrigation. On the other hand, our ignoring water impoundment, our use of observed rather than dynamic LAI, and the model's overestimation of runoff and drainage probably led to an underestimation of irrigation's effects. The most important of these errors are probably our irrigation over too large an area and the model's overestimation of runoff and drainage. These two errors should cancel each other to some extent on the global average, but probably led to an underestimation of irrigation's effects in India, eastern China and Southeast Asia, and an overestimation of its effects (by a factor of two or less) in many other regions.
Finally, many of our results are scale-dependent. Irrigated farmland affects its own microclimate much more than the large-scale results of this study might suggest. Crop yield depends on this microclimate, not on the average climate of a large grid cell. Regional studies have shown larger effects of irrigation over small areas (e.g., Bonfils and Lobell 2007; Kueppers et al. 2007); the present study should not be taken as a refutation of those regionalscale results. Furthermore, even our large-scale average results may be resolution-dependent. For example, a proper treatment of the kilometer-scale heterogeneity of irrigation might lead to increased precipitation through the generation of mesoscale circulations (Chen and Avissar 1994).

\section{Conclusions}

Global patterns of irrigation alter climate significantly in some large regions of the planet. Cooling effects tend to be greatest near irrigated areas in the season of heaviest irrigation, and are generally greater in dry regions. Consequently, irrigation appears to have caused the greatest cooling in northern mid-latitude regions. The effects are generally larger during the day than at night. While direct evaporative cooling is important, at least as much cooling seems to be caused by indirect effects such as increased cloud cover. The cooling in some regions, however, is offset by warming in other regions, predominantly the northern high latitudes, at least in our model. Dynamical changes, such as a slight strengthening of the Aleutian Low, seem primarily responsible for this high-latitude warming. On the global average, therefore, irrigation has a negligible effect on the near-surface temperature.

The modeled effects of irrigation depend strongly on both the volume and area of irrigation. Future modeling studies that include irrigation should therefore strive to get both of these values approximately correct. Where this is not possible, due to limitations of data availability or of the model, authors should at least report the volume and area of irrigation, a practice not followed in most irrigation studies to date. In a different set of simulations (not shown) we found that using a simple irrigation algorithm that kept all crops well-watered (similar to irrigation in L06) led to the application of almost 100 times too much water. This led to many unrealistic climatic effects. For example, the increased river runoff and the consequent freshening of the North Atlantic substantially weakened the ocean model's thermohaline circulation.

The large effects of irrigation in some regions show that changes in land management can be as important for climate as changes in land cover. These changes in land management should be given greater attention, both for modeling future climate and for understanding historical climate trends. For 
instance, Kueppers et al. (2007) and Bonfils and Lobell (2007) pointed out that in heavily irrigated semi-arid regions such as California's Central Valley, the irrigation cooling effect may be masking global warming. Water availability in many heavily irrigated regions is expected to decline in the future, whereas population growth and economic development in other regions will lead to increased irrigation (Vörösmarty et al. 2000; Alcamo et al. 2003). It is important to consider how these irrigation changes will interact with other future climatic changes.

Acknowledgments We thank NCAR's Advanced Study Program for sponsoring the "Art of Climate Modeling" summer colloquium, where we began this work. Mark Decker was also involved in that initial stage of the project. Jon Foley, Chris Kucharik and Mutlu Ozdogan all provided many helpful suggestions throughout every stage of this project. WJS was supported by a National Science Foundation Graduate Research Fellowship, BIC by the National Oceanic and Atmospheric Administration Global Change Postdoctoral Program, and NB by a Cooperative Institute for Research in Environmental Studies student fellowship and a grant from the National Oceanic and Atmospheric Administration's Climate and Global Change Program. The simulations were performed on NCAR supercomputers. NCAR is funded by the National Science Foundation.

\section{References}

Adegoke JO, Pielke RA, Eastman J, Mahmood R, Hubbard KG (2003) Impact of irrigation on midsummer surface fluxes and temperature under dry synoptic conditions: A regional atmospheric model study of the U.S. high plains. Mon Weather Rev 131:556-564. doi:10.1175/1520-0493(2003)131 $\leq 0556$ :IOIOMS $\geq 2.0$.CO;2

Alcamo J, Doll P, Henrichs T, Kaspar F, Lehner B, Rosch T, Siebert S (2003) Global estimates of water withdrawals and availability under current and future "business-as-usual" conditions. Hydro$\log$ Sci J 48:339-348. doi:10.1623/hysj.48.3.339.45278

Betts RA, Falloon PD, Goldewijk KK, Ramankutty N (2007) Biogeophysical effects of land use on climate: Model simulations of radiative forcing and large-scale temperature change. Agric For Meteorol 142:216-233. doi:10.1016/j.agrformet.2006.08.021

Bonfils C, Lobell D (2007) Empirical evidence for a recent slowdown in irrigation-induced cooling. Proc Natl Acad Sci USA 104:13582-13587. doi:10.1073/pnas.0700144104

Boucher O, Myhre G, Myhre A (2004) Direct human influence of irrigation on atmospheric water vapour and climate. Clim Dyn 22:597-603. doi:10.1007/s00382-004-0402-4

Bounoua L, DeFries R, Collatz GJ, Sellers P, Khan H (2002) Effects of land cover conversion on surface climate. Clim Change 52:29-64. doi:10.1023/A:1013051420309

Brovkin V, Ganopolski A, Claussen M, Kubatzki C, Petoukhov V (1999) Modelling climate response to historical land cover change. Global Ecol Biogeogr 8:509-517. doi:10.1046/j. 1365-2699.1999.00169.x

Chase TN, Pielke RA, Kittel TGF, Baron JS, Stohlgren TJ (1999) Potential impacts on Colorado Rocky Mountain weather due to land use changes on the adjacent Great Plains. J Geophys Res Atmos 104:16673-16690

Chen F, Avissar R (1994) Impact of land-surface moisture variability on local shallow convective cumulus and precipitation in large- scale models. J Appl Meteorol 33:1382-1401. doi:10.1175/15200450(1994)033 $\leq 1382:$ IOLSMV $\geq 2.0 . C O ; 2$

China State Statistical Bureau (2004) Statistical yearbook of China 2003. Economic Information \& Agency, Hong Kong

Collins WD, Rasch PJ, Boville BA, Hack JJ, McCaa JR, Williamson DL, Kiehl JT, Briegleb B, Bitz C, Lin S-J, Zhang M, Dai Y (2004) Description of the NCAR Community Atmosphere Model (CAM 3.0). Tech Rep NCAR/TN-464 + STR, National Center for Atmospheric Research, Boulder, CO

Collins WD, Rasch PJ, Boville BA, Hack JJ, McCaa JR, Williamson DL, Briegleb BP, Bitz CM, Lin SJ, Zhang MH (2006) The formulation and atmospheric simulation of the Community Atmosphere Model version 3 (CAM3). J Clim 19:2144-2161. doi:10.1175/JCLI3760.1

Dai A, Trenberth KE, Karl TR (1999) Effects of clouds, soil moisture, precipitation, and water vapor on diurnal temperature range. J Clim 12:2451-2473. doi:10.1175/1520-0442(1999)012 $\leq 2451$ : $\mathrm{EOCSMP} \geq 2.0 . \mathrm{CO} ; 2$

Dickinson RE, Oleson KW, Bonan G, Hoffman F, Thornton P, Vertenstein M, Yang ZL, Zeng XB (2006) The Community Land Model and its climate statistics as a component of the Community Climate System Model. J Clim 19:2302-2324. doi: 10.1175/JCLI3742.1

Doll P, Siebert S (2002) Global modeling of irrigation water requirements. Water Resour Res 38:1037. doi:10.1029/ 2001WR000355

Duffy PB, Bonfils C, Lobell D (2006) Interpreting recent temperature trends in California. EOS 88:409-410. doi:10.1029/ 2007EO410001

Foley JA, Costa MH, Delire C, Ramankutty N, Snyder P (2003) Green surprise? How terrestrial ecosystems could affect earth's climate. Front Ecol Environ 1:38-44

Foley JA, DeFries R, Asner GP, Barford C, Bonan G, Carpenter SR, Chapin FS, Coe MT, Daily GC, Gibbs HK, Helkowski JH, Holloway T, Howard EA, Kucharik CJ, Monfreda C, Patz JA, Prentice IC, Ramankutty N, Snyder PK (2005) Global consequences of land use. Science 309:570-574. doi:10.1126/science. 1111772

Food and Agriculture Organization (FAO) (2004) AQUASTAT 2003. Available via http://www.fao.org/nr/water/aquastat/main/index. stm

Gleick PH (1998) The world's water 1998-1999: The biennial report on freshwater resources. Island Press, Washington, D.C

Govindasamy B, Duffy PB, Caldeira K (2001) Land use changes and northern hemisphere cooling. Geophys Res Lett 28:291-294. doi:10.1029/2000GL006121

Guerra LC, Bhuiyan SI, Tuong TP, Barker R (1998) Producing more rice with less water. SWIM paper 5. International Water Management Institute, Colombo, Sri Lanka

Haddeland I, Lettenmaier DP, Skaugen T (2006) Effects of irrigation on the water and energy balances of the Colorado and Mekong river basins. J Hydrol 324:210-223. doi:10.1016/j.jhydrol.2005. 09.028

Hansen MC, DeFries RS, Townshend JRG, Carroll M, Dimiceli C, Sohlberg RA (2003) Global percent tree cover at a spatial resolution of 500 meters: First results of the MODIS vegetation continuous fields algorithm. Earth Interact 7:1-15. doi:10.1175/ 1087-3562(2003)007 $\leq 0001: G P T C A A \geq 2.0 . C O ; 2$

Helkowski JH (2004) Global patterns of soil moisture and runoff: An assessment of water availability, M.S. thesis. University of Wisconsin - Madison, Madison, WI

Hurrell JW, Hack JJ, Phillips AS, Caron J, Yin J (2006) The dynamical simulation of the Community Atmosphere Model version 3 (CAM3). J Clim 19:2162-2183. doi:10.1175/ JCLI3762.1 
Joshi AK, Mishra B, Chatrath R, Ferrara GO, Singh RP (2007) Wheat improvement in India: Present status, emerging challenges and future prospects. Euphytica 157:431-446. doi:10.1007/ s10681-007-9385-7

Kucharik CJ, Twine TE (2007) Residue, respiration, and residuals: Evaluation of a dynamic agroecosystem model using eddy flux measurements and biometric data. Agric For Meteorol 146:134158. doi:10.1016/j.agrformet.2007.05.011

Kueppers LM, Snyder MA, Sloan LC (2007) Irrigation cooling effect: Regional climate forcing by land-use change. Geophys Res Lett 34. Doi:10.1029/2006GL028679

Kuo S (2001) Part III country papers: Republic of China. In: Asian Productivity Organization, Water use efficiency in irrigation in Asia. Asian Productivity Organization, Taipei, Taiwan

Lawrence PJ, Chase TN (2007) Representing a new MODIS consistent land surface in the Community Land Model (CLM 3.0). J Geophys Res Biogeosci 112:G01023

Leff B, Ramankutty N, Foley JA (2004) Geographic distribution of major crops across the world. Global Biogeochem Cycles 18:GB1009. doi:10.1029/2003GB002108

Lobell DB, Bala G, Duffy PB (2006) Biogeophysical impacts of cropland management changes on climate. Geophys Res Lett 33:L06708. doi:10.1029/2005GL025492

Mahmood R, Foster SA, Keeling T, Hubbard KG, Carlson C, Leeper $R$ (2006) Impacts of irrigation on 20th century temperature in the northern Great Plains. Global Planet Change 54:1-18. doi: 10.1016/j.gloplacha.2005.10.004

Matthews HD, Weaver AJ, Meissner KJ, Gillett NP, Eby M (2004) Natural and anthropogenic climate change: Incorporating historical land cover change, vegetation dynamics and the global carbon cycle. Clim Dyn 22:461-479. doi:10.1007/s00382-0040392-2

Myneni RB, Hoffman S, Knyazikhin Y, Privette JL, Glassy J, Tian Y, Wang Y, Song X, Zhang Y, Smith GR, Lotsch A, Friedl M, Morisette JT, Votava P, Nemani RR, Running SW (2002) Global products of vegetation leaf area and fraction absorbed PAR from year one of MODIS data. Remote Sens Environ 83:214-231. doi: 10.1016/S0034-4257(02)00074-3

Oleson KW, Dai Y, Bonan G, Bosilovich M, Dickinson R, Dirmeyer P, Hoffman F, Houser P, Levis S, Niu G-Y, Thornton P,
Vertenstein M, Yang Z-L, Zeng X (2004) Technical description of the community land model (CLM). Tech Rep NCAR/TN$461+$ STR, National Center for Atmospheric Research, Boulder, $\mathrm{CO}$

Oleson KW, Niu GY, Yang ZL, Lawrence DM, Thornton PE, Lawrence PJ, Stockli R, Dickinson RE, Bonan GB, Levis S, Dai A, Qian T (2008) Improvements to the community land model and their impact on the hydrological cycle. J Geophys Res Biogeosci 113:G01021

Postel S (1999) Pillar of sand: Can the irrigation miracle last? W.W. Norton \& Co, New York

Qian TT, Dai AG, Trenberth KE, Oleson KW (2006) Simulation of global land surface conditions from 1948 to 2004. Part I: Forcing data and evaluations. J Hydrometeorol 7:953-975. doi:10.1175/ JHM540.1

Ramankutty N, Foley JA (1999) Estimating historical changes in global land cover: Croplands from 1700 to 1992. Global Biogeochem Cycles 13:997-1027. doi:10.1029/1999GB900046

Schlesinger WH (1999) Carbon and agriculture - carbon sequestration in soils. Science 284:2095-2095. doi:10.1126/science.284. 5423.2095

Shiklomanov IA (2000) Appraisal and assessment of world water resources. Water Int 25:11-32

Siebert S, Döll P, Hoogeveen J (2001) Global map of irrigated areas version 2.0. Center for Environmental Systems Research, University of Kassel, Germany/Food and Agriculture Organization of the United Nations, Rome, Italy

Siebert S, Döll P, Hoogeveen J, Faures JM, Frenken K, Feick S (2005) Development and validation of the global map of irrigation areas. Hydrol Earth Syst Sc 9:535-547

United States Geological Survey (USGS) (2004) 1995 water-use data. Available via http://water.usgs.gov/watuse/spread95.html

Vörösmarty CJ, Green P, Salisbury J, Lammers RB (2000) Global water resources: Vulnerability from climate change and population growth. Science 289:284-288. doi:10.1126/science.289. 5477.284

Zhao M, Pitman AJ, Chase T (2001) The impact of land cover change on the atmospheric circulation. Clim Dyn 17:467-477. doi: 10.1007/PL00013740 